\title{
Impact of the Southern Ecuadorian Andes on Oxygen and Hydrogen Isotopes in Precipitation
}

\author{
Aude Gébelin ${ }^{1 *}$, Cesar Witt ${ }^{2}$, Maksymilian Radkiewicz ${ }^{1 *}$ and Andreas Mulch ${ }^{3,4}$ \\ ${ }^{1}$ School of Geography, Earth and Environmental Sciences, University of Plymouth, Plymouth, United Kingdom, ${ }^{2}$ Univ, Lille, CNRS, \\ Univ, Littoral Côte d'Opale, UMR 8187, LOG, Laboratoire d'Océanologie et de Géosciences, Lille, France, ${ }^{3}$ Senckenberg \\ Biodiversity and Climate Research Centre (SBiK-F), Frankfurt, Germany, ${ }^{4}$ Institute of Geosciences, Goethe University Frankfurt, \\ Frankfurt, Germany
}

OPEN ACCESS

Edited by:

Alexis Licht,

University of Washington,

United States

Reviewed by:

Lin Li,

Rochester Institute of Technology,

United States

Lily Jackson,

University of Texas at Austin,

United States

Landon Burgener,

North Carolina State University, United States

*Correspondence: Aude Gébelin

aude.gebelin@gmail.com.uk

Maksymilian Radkiewicz

maxradkiewicz@gmail.com

Specialty section:

This article was submitted to Quaternary Science, Geomorphology and Paleoenvironment,

a section of the journal

Frontiers in Earth Science

Received: 05 February 2021

Accepted: 05 May 2021

Published: 28 May 2021

Citation:

Gébelin A, Witt C, Radkiewicz M and Mulch A (2021) Impact of the Southern Ecuadorian Andes on Oxygen and Hydrogen Isotopes in Precipitation.

Front. Earth Sci. 9:664590.

doi: 10.3389/feart.2021.664590
Determining how the elevation of the Northern Andes has evolved over time is of paramount importance for understanding the response of the Northern Andes to deformational and geodynamic processes and its role as an orographic barrier for atmospheric vapor transport over geologic time. However, a fundamental requirement when using stable isotope data for paleoaltimetry reconstructions is knowledge about the present-day changes of $\delta^{18} \mathrm{O}$ and $\delta \mathrm{D}$ with elevation (isotopic lapse rate). This study defines the present-day river isotopic lapse rate near the Equator $\left(\sim 3^{\circ} \mathrm{S}\right)$ based on analysis of $\delta^{18} \mathrm{O}$ and $\delta D$ of surface waters collected from streams across the Western Cordillera and the Inter-Andean depression in Southern Ecuador. The results for the two domains show a decrease of $\delta^{18} \mathrm{O}$ with elevation which fits a linear regression with a slope of $-0.18 \%$ / $100 \mathrm{~m}\left(\mathrm{R}^{2}=0.73, n=83\right)$. However, we establish a present-day lapse rate of $-0.15 \%$ o/ $100 \mathrm{~m}$ for $\delta^{18} \mathrm{O}\left(\mathrm{R}^{2}=0.88, n=19\right)$ and $-1.4 \% / 100 \mathrm{~m}$ for $\delta \mathrm{D}\left(\mathrm{R}^{2}=0.93, n=19\right)$ from water samples collected along the west facing slopes of the Western Ecuadorian Cordillera which is mainly subject to moisture transport from the Pacific. We argue that this empirical relationship, consistent with those obtained in different tropical areas of the world, can inform stable isotope paleoaltimetry reconstructions in tropical latitudes.

\footnotetext{
Keywords: stable isotope paleoaltimetry, isotopic lapse rate, tropical precipitation, hydrogen isotopes, oxygen isotopes, Northern Andes, Western Southern Ecuadorian Cordillera, Inter-Andean depression
}

\section{INTRODUCTION}

The long-term climatic evolution and atmospheric circulation patterns of the Earth are influenced on the first order by the topography of large mountain chains (e.g., Molnar and England, 1990; Boos and Kuang, 2010; Barnes et al., 2012).

The Andes are a non-collisional subduction orogen and represent one of the main topographic features on Earth. However, uncertainties remain about how long this belt has been acting as a barrier to atmospheric circulation and moisture transport (e.g., Garzione et al., 2006; Garzione et al., 2008; Rech et al., 2006; Barnes and Ehlers, 2009; Ehlers and Poulson, 2009; Mulch 2016; Garzione et al., 2017; Sundell et al., 2019). Most studies aiming at understanding the links among geodynamic processes, Andean topography, and climate have focused on the Southern and Central Andes; the role and overall long-term landscape evolution of the Northern Andes remains enigmatic. This negligence is partly due to the scarce paleoaltimetry data obtained in the Northern Andes, and especially in the Ecuadorian Andes, a region of intense debate about the timing and rate of topographic development (e.g., Steinmann et al., 1999; Gregory-Wodzicky, 2000; Hungerbuhler et al., 2002; Witt et al., 2017; Jackson et al., 2019). 


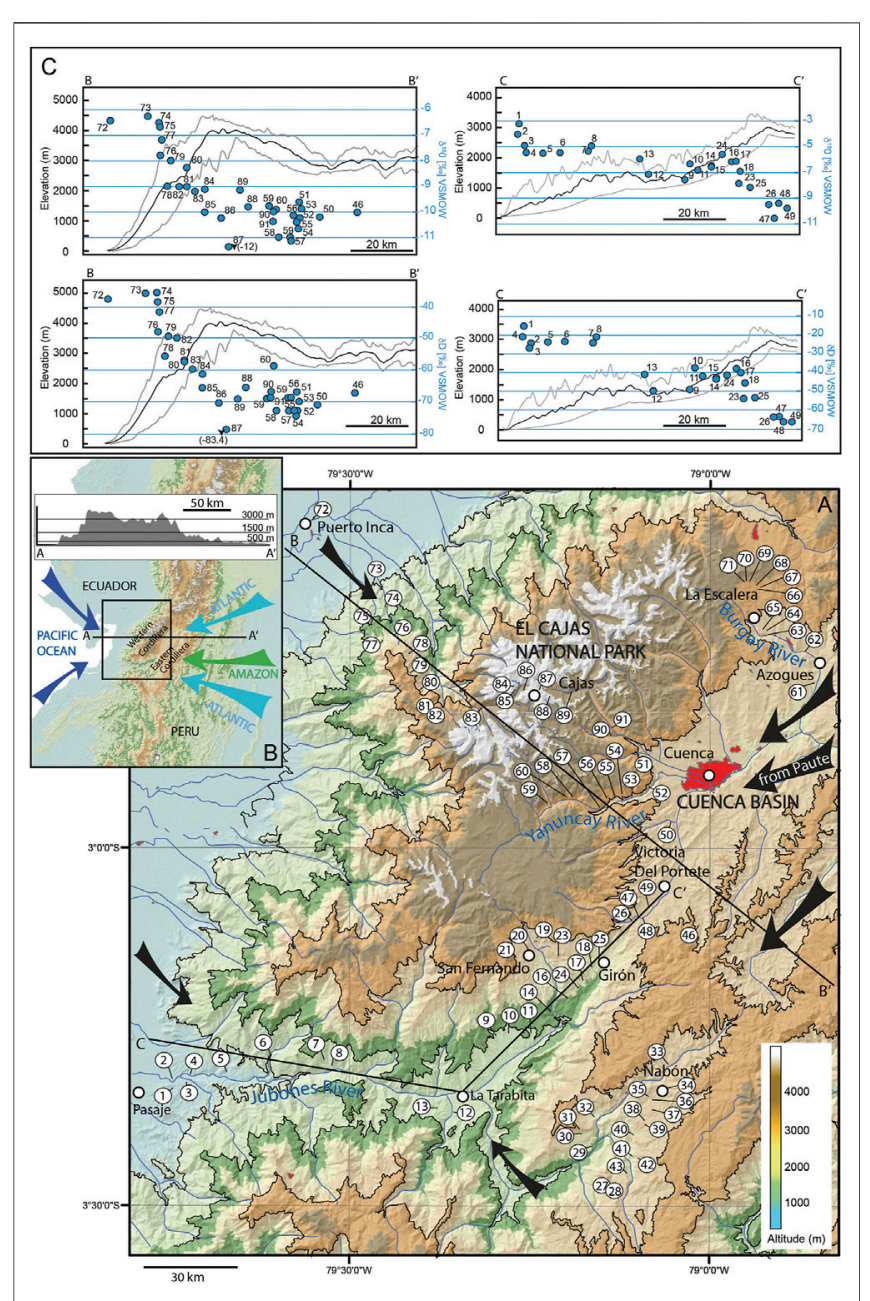

FIGURE 1 | (A) Digital elevation model (90 m resolution) of Southern Ecuador showing water sample locations. Black arrows indicate direction and movements of air masses during our water samples collection. (B) Schematic diagram showing major air mass trajectories affecting Ecuador as well as an E-W trending elevation profile across the Southern Ecuadorian Andes. (C) Modern $\delta^{18} \mathrm{O}_{\text {water }}$ and $\delta \mathrm{D}_{\text {water }}$ values (blue dots) from our sampling sites along two main transects across the Western Southern Ecuadorian Cordillera (see location in A). Minimum and maximum topographic profiles (gray lines) were obtained at a swath distance of $5 \mathrm{~km}$ at each side of the main central section.

Most paleoaltimetry studies use the stable oxygen $\left(\delta^{18} \mathrm{O}\right)$ and hydrogen $(\delta D)$ isotopic composition of meteoric water that scales with elevation in a predictable fashion to retrieve the elevation signal from near-surface paleoenvironmental archives (e.g., Garzione et al., 2000; Mulch et al., 2006; Sundell et al., 2019) or crustal-scale deformation zones (e.g., Mulch et al., 2004; Gébelin et al., 2012; Gébelin et al., 2013). This relationship results from distillation of heavy isotopes $\left({ }^{18} \mathrm{O}\right.$ or $\left.\mathrm{D}\right)$ through condensation and precipitation as air masses rising across a mountain range cool adiabatically during ascent. As a result, oxygen $\left(\delta^{18} \mathrm{O}\right)$ and hydrogen $(\delta \mathrm{D})$ isotope ratios of rainfall scale systematically with elevation on the windward side of a mountain range. Compilations of isotope data sets from regions in the low to mid-latitudes provide an average of $\sim 2.8 \%$ in $\delta^{18} \mathrm{O}$ or $\sim 20 \%$ in $\delta \mathrm{D}$ per $\mathrm{km}$ (Poage and Chamberlain, 2001; Quade et al., 2011).

Here, we present the first comprehensive study of this empirical relationship near the Equator across the Western Andean Cordillera and the Inter-Andean depression in southern Ecuador by analysing surface waters from tributaries along five transects (Figure 1, Supplementary Table S1). In agreement with previous studies identifying the altitude effect on the isotopic composition of tropical precipitation (e.g., Garcia et al., 1998; Gonfiantini et al., 2001; Saylor et al., 2009), our results indicate that $\delta^{18} \mathrm{O}$ and $\delta \mathrm{D}$ values of tributary waters decrease systematically as a function of increasing elevation on the windward side of the Western Cordillera, yet with a lower lapse rate than commonly observed at mid-latitudes (e.g., Poage and Chamberlain, 2001). Projecting such isotope-elevation relationship to past environments is inherently difficult, yet an important parameter in paleoaltimetry reconstructions. Present-day lapse rates established in different climate zones, latitudes or hydrological settings allows us to explore how different environmental settings in the past may have affected isotope lapse rates.

\section{CLIMATE OF THE ECUADORIAN ANDES}

Topography exerts an important control on atmospheric moisture flux over the Northern Andes (Garcia et al., 1998; Windhorst et al., 2013). Due to the presence of two northsouth trending Eastern and Western Cordilleras separated by an Inter-Andean valley, their equatorial location, at the junction between the Pacific Ocean and the Amazon Basin, the Ecuadorian Andes are characterized by a complex climate (Figure 1B). Currently, Ecuador is influenced by two main precipitation sources: 1) Air masses originating from the Pacific (Garcia et al., 1998), and 2) Atlantic air masses carried across the Amazon Basin (Windhorst et al., 2013). Also, precipitation regime and atmospheric circulation patterns in Ecuador are governed by three main factors: 1) Altitude of the Andes acting as a weather divide between Pacific air masses from the west and Atlantic air masses from the east (Garreaud et al., 2009), 2) Passage of the Intertropical Convergence Zone (ITCZ) (e.g., Rozanski and Araguas-Araguas, 1995), and 3) El Niño-Southern Oscillation (ENSO) (e.g., Rossel and Cardier, 2009). The Western Cordillera and coastal areas are affected by western trade winds advecting moisture from the Pacific Ocean (Emsk, 2007). This Pacific domain is marked by a unimodal precipitation regime with increased rainfall from December to April that accounts for more than $90 \%$ of annual precipitation and coincides with the southernmost extent of the ITCZ (Rozanski and AraguasAraguas, 1995; Garcia et al., 1998; Campozano et al., 2016).

The South Ecuadorian Coast is affected by ENSO cyclicity that brings warm surface waters carried by trade winds from the West Pacific and causes heavy rainfall during the El Niño years (Philander, 1983; Rossel and Cardier, 2009). Convective storms from the Pacific cause a significant decrease in $\delta^{18} \mathrm{O}$ and $\delta \mathrm{D}$ values of precipitation in the coastal areas of Ecuador (Garcia et al., 1998). The impact of ENSO on precipitation 
depends on the local topography; it is highest at low to moderate elevations on west facing slopes of the Cordillera $(<1500 \mathrm{~m})$ and negligible at high elevations (Rossel et al., 1998; Rollenbeck and Bendix, 2011; Ochoa et al., 2016). Rainfall intensity also depends on the latitude and is higher in the north (> 700 and 3,500 $\mathrm{mm}$ in the coast and foothills, respectively) than in the south $(<80$ and $800 \mathrm{~mm}$ in the coast and foothills, respectively) (Garcia et al., 1998). This latitudinal effect is reflected in the isotopic composition of precipitation of Pacific coastal stations, which display lower mean $\delta^{18} \mathrm{O}_{\text {water }}$ values in the north $(\sim-5 \%)$ than in the south ( - $\%$ o) (Garcia et al., 1998).

The Eastern Cordillera is controlled by moisture-bearing winds from the Atlantic and the Amazon Basin and not by the Pacific westerlies (Emck, 2007; Windhorst et al., 2013). Atlantic air masses are carried by strong south-easterly winds, that once they have reached the eastern slopes of the Eastern Cordillera, are adiabatically lifted forming the Andean Occurring System (AOS, Campozano et al., 2016) that is progressively transported to the Inter-Andean depression (Celleri et al., 2007; Windhorst et al., 2013; Mora et al., 2014; Ochoa et al., 2016).

The climate of the Inter-Andean valley is influenced by moisture sources in the Western Pacific and continental and tropical Atlantic air masses (Vuille et al., 2000). Strong southeasterly trade winds carry moisture from the Amazon and enter the Inter-Andean valley leading to a mixing of moisture with Pacific trade winds (Campozano et al., 2016). Air masses in the Inter-Andean depression can also originate in the Atlantic, and may get enriched in ${ }^{18} \mathrm{O}$ or $\mathrm{D}$ due to high evapotranspiration during passage over the Amazon Basin (e.g., Salati et al., 1979). The Cuenca Basin (Figure 1A) is part of this domain and has an outlet towards the east, into the Amazon Basin (Ochoa et al., 2016). In contrast to the Pacific domain that shows a unimodal distribution of precipitation, the Inter-Andean depression is characterized by two contrasting rainfall regimes, a unimodal (UMR) and a bimodal (BMR) regime that respectively cover $\sim 15$ and $\sim 85 \%$ of the Cuenca basin area (Celleri et al., 2007). Based on different distributions of mean annual rainfall, two UMR with a single rainfall peak in June and July (UM1: 2,900-3,400 $\mathrm{mm} \mathrm{a}^{-1}$ and UM2: $1,100-1,600 \mathrm{~mm} \mathrm{a}^{-1}$ ) are defined in the eastern part of the basin, and two BMR with rainfall peaks in April and October (BM1: 660-100 $\mathrm{mm} \mathrm{a}^{-1}$ and BM2: $1,000-1,800 \mathrm{~mm} \mathrm{a}^{-1}$ ) occur on the high eastern and western flanks of the basin (see Figure 5 in Celleri et al., 2007). The UMR is closely related to the AOS reaching the basin via the Paute Canyon (Figure 1A), and the difference in precipitation amount is interpreted to reflect an abrupt change in elevation where moisture originating from the Amazon Basin produces high orographic rainfall volumes (UM1), followed by reduced orographic precipitation (UM2) (Celleri et al., 2007). The BMR is identified at the junction between the Inter-Andean depression, the Amazon and Pacific basin and is controlled by the seasonal north-south migration of the ITCZ that causes peak rainfall and low $\delta^{18} \mathrm{O}$ (and low $\delta \mathrm{D}$ ) precipitation values in March-April and then October-November (Rozanski and Araguas-Araguas, 1995; Garcia et al., 1998; Celleri et al., 2007; Ochoa et al., 2016).

\section{METHODS}

To establish a river-based $\delta \mathrm{D}$ - and $\delta^{18} \mathrm{O}$-elevation relationship at the Equator, we sampled a total of 89 surface waters from perennial streams during the dry season (mid September) from an array of elevations across the Southern part of the Ecuadorian Western Cordillera and the adjacent Inter-Andean depression (Figure 1 and Supplementary Table S1). River-based isotope-elevation relationships may be skewed to select elevation intervals due to uneven precipitation intensity within a given hypsometry (e.g., Bookhagen and Burbank, 2006) or biased by groundwater recharge from unknown catchment sizes. However, they have proven extremely informative as a) they reflect the competing effects of climatic and topographic controls on regional isotopic lapse rates (e.g., Rohrmann et al., 2014), and b) contribute largely to averaging precipitation events or seasonality of precipitation (e.g., Garzione et al., 2000; Schemmel et al., 2013). We hence feel confident that, with respect to paleaoaltimetry applications where time scales of isotopic proxy development play an important role, such riverbased lapse rates are robust since nature has already provided a lot of the spatial averaging.

We established two main transects (Puerto Inca and Pasaje) on the windward side from the Ecuadorian Pacific coast (near sea level) to the top of the mountain range $(\sim 4,000 \mathrm{~m})$. We analyzed $\delta \mathrm{D}$ and $\delta^{18} \mathrm{O}$ values from tributaries along three transects in the Inter-Andean valley. Two of them have been conducted in the Cuenca Basin along the Yanuncay and Burgay Rivers and one further south in the Nabón Basin to 1) test whether the $\delta \mathrm{D}$ and $\delta^{18} \mathrm{O}$ values of stream waters reflect the presence of an orographic rain shadow on the leeward side of the Western Cordillera, 2) analyze surface waters sourced at high elevations, and 3) evaluate the influence of the mixing between Pacific and Atlantic air masses as well as from the Amazon rainforest on $\delta \mathrm{D}$ and $\delta^{18} \mathrm{O}$ values in precipitation. The deuterium excess values defined as $\mathrm{d}=\delta \mathrm{D}-8 \mathrm{x} \delta^{18} \mathrm{O}$ (Craig and Gordon, 1965) have been used to estimate the amount of evaporation in meteoric water that may have affected this depression area (e.g., Windhorst et al., 2013).

At each sampling site $30 \mathrm{ml}$ of water was collected in polyethylene bottles with little to no air in the closed bottles. Samples were stored in the dark at room temperature until returned to the laboratory for analysis. Measurements of stable hydrogen $(\delta \mathrm{D})$ and oxygen $\left(\delta^{18} \mathrm{O}\right)$ isotope ratios were carried out on $1 \mathrm{ml}$ aliquots using an LGR LWIA-24d (CRD Laser Spectroscopy) liquid isotope water analyzer in the joint Goethe University-Senckenberg BiK-F Stable Isotope Facility, Frankfurt. $\delta \mathrm{D}$ and $\delta^{18} \mathrm{O}$ values were corrected against internal lab standards that are calibrated against VSMOW. The analytical precision is 1.0 and $0.3 \%$ o (both $2 \sigma$ ) for $\delta \mathrm{D}$ and $\delta^{18} \mathrm{O}$, respectively. Absolute stable isotope values range from -15 to $-83 \%$ for $\delta \mathrm{D}$ and -3.2 to $-12.0 \%$ for $\delta^{18} \mathrm{O}$ (Figure 2 and Supplementary Table S1).

Sampling perennial streams provides an amount-weighted long-term average of precipitation for each catchment, but can lead to an underestimation of the elevation at which the majority of the precipitation falls, especially in high-relief or large catchments areas (Currie, et al., 2005; Rowley and Garzione, 

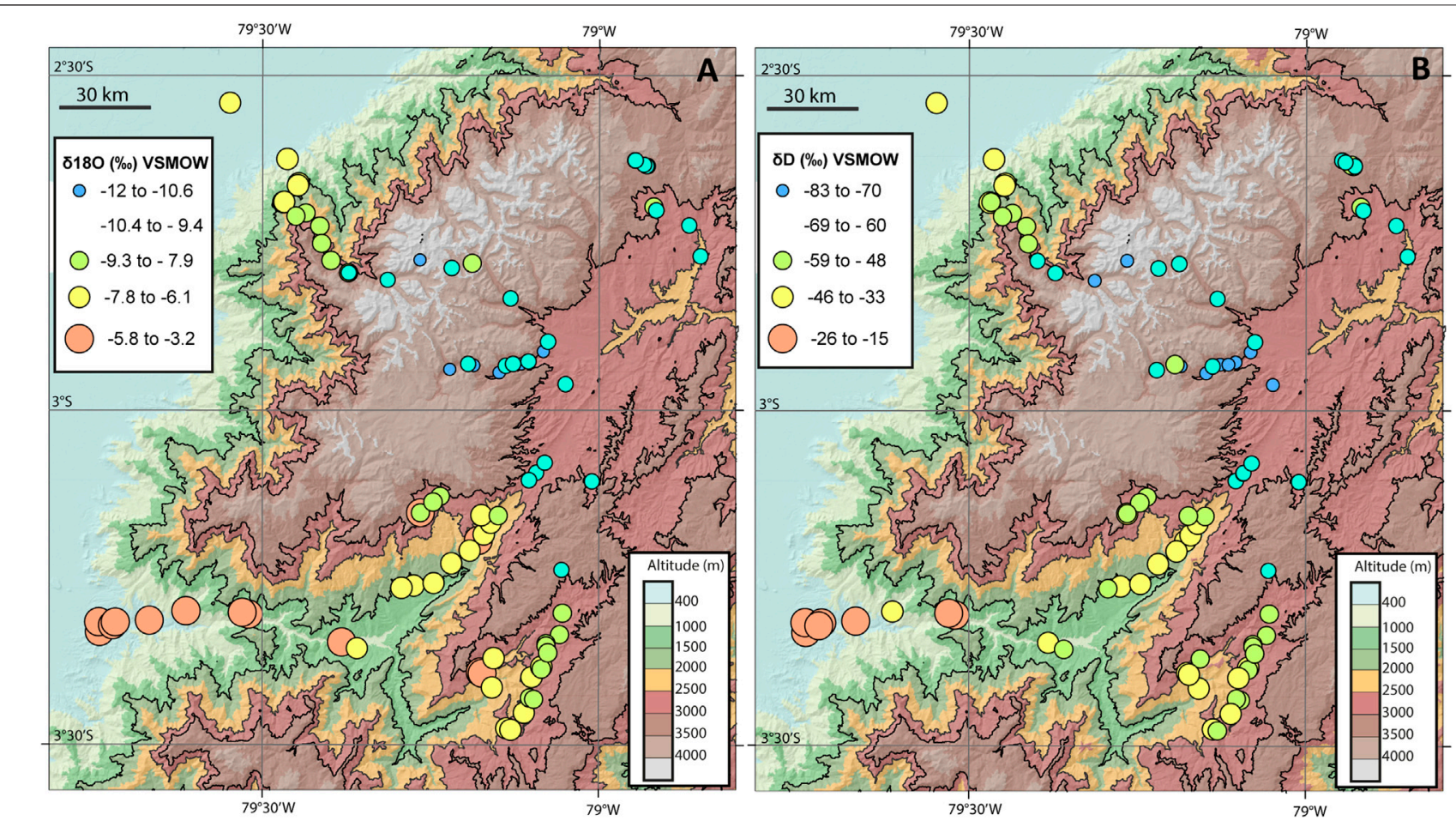

FIGURE 2 | Spatial distribution of $\delta^{18} \mathrm{O}(\mathbf{A})$ and $\delta D(\mathbf{B})$ values from our water samples collected over southern Ecuador.

2007; Quade et al., 2011; Schemmel et al., 2013). We calculated mean catchment elevations for each sample using an elevationweighted flow accumulation model in ESRI ${ }^{\circledR}$ ArcGISTM 10.0 based on version 11 of the National Aeronautics and Space Administration (NASA) ASTER Global Digital Elevation Model at a spatial resolution of 1 arc-second $(\sim 30 \mathrm{~m}) \cdot \delta^{18} \mathrm{O}$ and $\delta \mathrm{D}$ lapse rates use results from all water samples except 1) WS21 (lake de Busa; Pasaje transect), WS30 and WS31 (lake and related stream; Nabón Basin) that reflect evaporative lake conditions, 2) WS61 and WS62 (near Azogues; Cuenca Basin) affected by urban pollution and, 3) WS72 (Canar River; Puerto Inca transect) for which an accurate mean catchment elevation calculation is difficult due to large catchment size and insignificant relief.

\section{RESULTS}

Two main observations characterize our $\delta \mathrm{D}$ and $\delta^{18} \mathrm{O}$ data. 1) Air masses from the Pacific Ocean that directly rise across the Western Cordillera (Puerto Inca transect) experience Rayleigh distillation on the windward side; $\delta \mathrm{D}$ and $\delta^{18} \mathrm{O}$ values define a linear relationship between $\delta^{18} \mathrm{O}$ and altitude of $-0.15 \% / 100 \mathrm{~m}$ (Figure 3A) $(\delta \mathrm{D}=-1.4 \% / 100 \mathrm{~m}$; Figure 3B). 2) The $\delta \mathrm{D}$ and $\delta^{18} \mathrm{O}$ values of precipitation in the Inter-Andean valley cannot be directly correlated with elevation; they display additional variability that can be explained by a combination of factors such as mixing of air masses from the Pacific, the Atlantic and the Amazon Basin, evaporation, and seasonality.

\section{Spatial Distribution of $\delta \mathrm{D}$ and $\delta^{18} \mathrm{O}$ Values}

We observe a generally good correlation between $\delta \mathrm{D}$ and $\delta^{18} \mathrm{O}$ values of surface water and elevation at the map scale of southern Ecuador. On the windward flanks of the Western Cordillera, between Puerto Inca and El Cajas National Park, low elevation areas $(0<$ mean catchment elevations $<2000 \mathrm{~m}$ ) display relatively high $\delta \mathrm{D}$ and $\delta^{18} \mathrm{O}$ values ranging from -42 to $-36 \%$ and -7.2 to $-6.3 \%$, respectively, and contrast mountainous areas $(2000 \mathrm{~m}<$ mean catchment elevations $<4200 \mathrm{~m}$ ) with $\delta \mathrm{D}=-83$ to $-48 \%$ and $\delta^{18} \mathrm{O}=-12.0$ to $-7.8 \%$ for $\delta^{18} \mathrm{O}$ (Figures 1,2 and Supplementary Table S1). We additionally collected water samples further south between $\sim 50 \mathrm{~m}$ and $\sim 2,800 \mathrm{~m}$ elevation along the Pasaje transect (Figure 1A). All samples show strong correlation with elevation with $\delta^{18} \mathrm{O}$ values varying from -3.2 to $-10.6 \%$ o between the lowest $(\sim 300 \mathrm{~m})$ and highest $(\sim 3000 \mathrm{~m})$ mean catchment elevation while equivalent $\delta \mathrm{D}$ values range between -15 and $-71 \%$ (Figures 1C,2 and Supplementary Table S1). The difference in $\delta \mathrm{D}$ and $\delta^{18} \mathrm{O}$ values between lowland and mountainous areas on the windward flanks of the Western Cordillera is also observed in deuterium excess values with higher $d$-excess values $(d=15.0 \pm 3.5)$ below 2,000 m mean catchment elevations when compared to the highlands $(\mathrm{d}=11.0 \pm$ 3.4) (Supplementary Figure 1S).

We further collected water samples between the Western and Eastern Cordilleras, in the Cuenca Basin and the Nabón area (Figure 1A) including tributaries of the Yanuncay River with sampling elevations varying from 3,239 and $2,689 \mathrm{~m}$ (Supplementary Table S1). $\quad \delta^{18} \mathrm{O}$ values display large variability between -11.2 and $-9.6 \%$ and $\delta \mathrm{D}$ values are low 


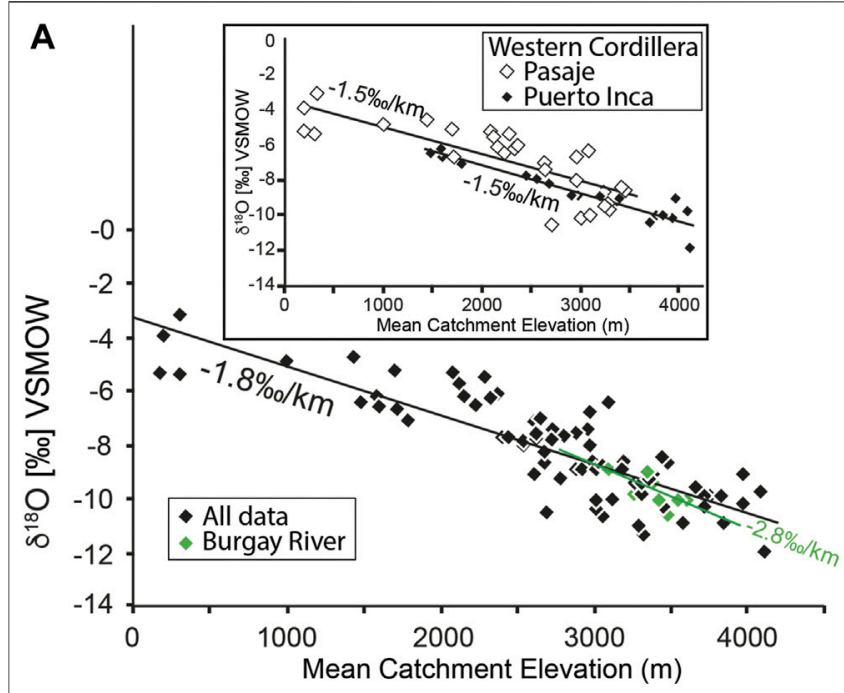

B

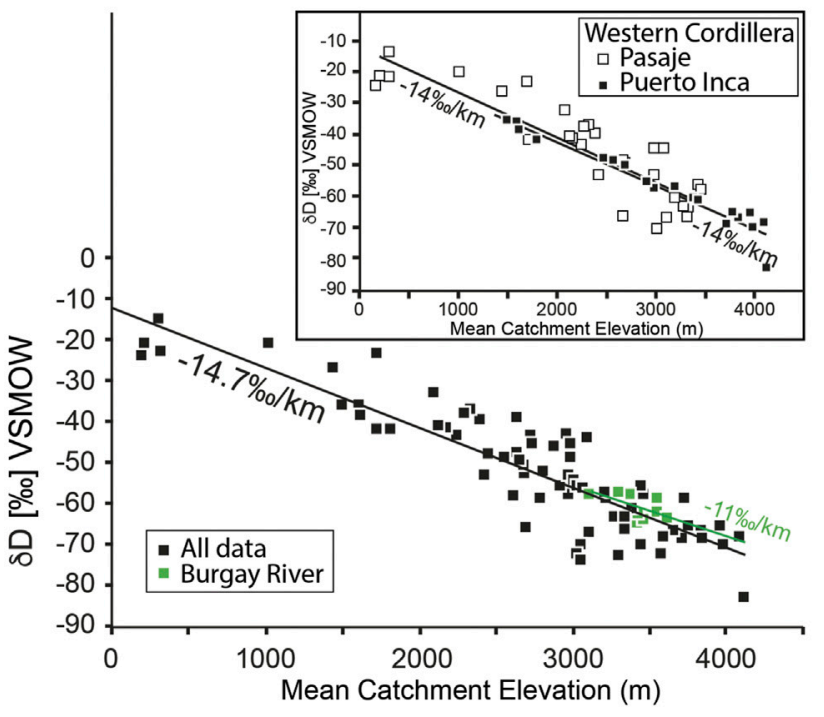

FIGURE 3 | (A) $\delta^{18} \mathrm{O}$ of river water vs. mean catchment elevation for all data ( $n=83$, black diamonds) defining a slope of $-1.8 \%$ / km (or $-0.18 \%$ / $100 \mathrm{~m}, \mathrm{R}^{2}=0.73$ ). Highlighted using green diamonds are samples collected in the Cuenca basin along the Burgay River that define an isotope-elevation lapse rate of $-2.8 \% / \mathrm{km}$ (or $-0.28 \% \circ / 100 \mathrm{~m}$ ). Inset: Plot of the $\delta^{18} \mathrm{O}$ of river water vs. mean catchment elevation $(\mathrm{m})$ for the Puerto Inca (small black diamonds) and Pasaje (small white diamonds) transects (windward side of the Western Ecuadorian Cordillera). Note that both transects provide a same lapse rate of $-1.5 \% / \mathrm{km}$ (or $-0.15 \% / 100 \mathrm{~m}$ ). (B) $\delta \mathrm{D}$ of river water vs. mean catchment elevation for all data ( $n=83$, black squares) providing a slope of $-14.7 \%$ / km (or $-1.47 \%$ / $100 \mathrm{~m}, \mathrm{R}^{2}=0.79$ ). Highlighted using green squares are samples collected in the Cuenca basin along the Burgay River that define an elevation lapse rate of $-11 \% / \mathrm{km}$ (or $-1.1 \% \mathrm{o} / 100 \mathrm{~m}$ ). Inset highlights data from the Puerto Inca and Pasaje transects plotted against mean catchment elevation. The decrease in $\delta \mathrm{D}$ values on the windward side of the Western Cordillera allows to define an isotopic lapse rate for both transects of $-14.7 \%$ / km (or $-1.47 \%$ o/100 m).

ranging from -75 to $-59 \%$ (Figure 2 and Supplementary Table S1).

We further focused on the north-north east part of the Cuenca region where we sampled tributaries of the Burgay River between

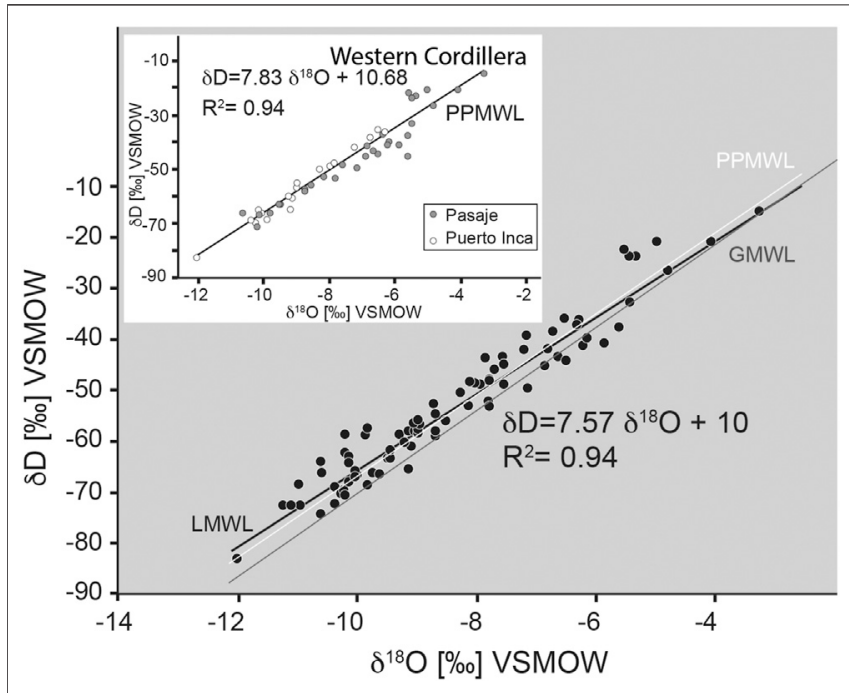

FIGURE $4 \mid \delta D$ vs. $\delta^{18} \mathrm{O}$ values of water samples allowing to define LMWL (Local Meteoric Water Line) and PPMWL (Puerto Inca-Pasaje Meteoric Water Line). LMWL has been defined from all our sampling sites (black circles, $n=83$ ). GMWL: Global Meteoric Water Line defined by Rozanski et al. (1993). Inset highlights PPMWL defined from values obtained from the Puerto Inca (white circles) and Pasaje (grey samples) that cross the Western Ecuadorian Cordillera. (See text for explanations).

Azogues and La Escalera (Figure 1A). $\delta^{18} \mathrm{O}$ and $\delta \mathrm{D}$ values vary from -10.6 to $-9.0 \%$ and -65 to $-58 \%$, respectively (Figure 2 and Supplementary Table S1).

Finally, we collected water samples from the Nabón area (Figure 1A), located within close proximity of the Amazon rainforest. Sampling occurred between 2,340 and 2,754 $\mathrm{m}$ of elevation. $\delta^{18} \mathrm{O}$ and $\delta \mathrm{D}$ values vary between -9.28 and $-7.52 \%$ and -59 to $-44 \%$ respectively and are generally higher than those obtained from the two other areas investigated in the Inter-Andean valley (Figure 2 and Supplementary Table S1). Although mean catchment elevations are systematically above 2,000 m elevation, $\mathrm{d}$-excess values are generally higher than those in high areas of the windward side of the Western Cordillera with $\mathrm{d}=14.0 \pm 3.7$ for Yanuncay, $\mathrm{d}=17.1 \pm 3.2$ for Burgay, and $\mathrm{d}=12.8 \pm 7.4$ for Nabón (Supplementary Table S1 and Supplementary Figure 1S).

\section{Meteoric Water Lines}

The $\delta \mathrm{D}$ and $\delta^{18} \mathrm{O}$ values of all our surface water samples collected in southern Ecuador define a Local Meteoric Water line (LMWL) with $\delta \mathrm{D}=7.57 \delta^{18} \mathrm{O}+10\left(\mathrm{R}^{2}=0.94\right)$ (Figure 4). When plotting only results from the windward side of the Western Cordillera (Puerto Inca and Pasaje transects) we obtain a meteoric water line with $\delta \mathrm{D}=7.83 \delta^{18} \mathrm{O}+10.68\left(\mathrm{PPMWL}, \mathrm{R}^{2}=0.94\right)$ (Figure 4). The close resemblance of the LMWL and PPMWL with the GMWL $\left(\delta \mathrm{D}=8.17 \delta^{18} \mathrm{O}+10.35\right.$; Rozanski et al. (1993) highlights the robustness of our results.

\section{Establishment of Isotopic Lapse Rates}

We evaluated the magnitude of $\delta \mathrm{D}$ and $\delta^{18} \mathrm{O}$ gradients across the Western Cordillera based on the results obtained on the windward side of the range. Some studies have constrained the 
absolute elevation of precipitation by directly sampling rainfall via open rainfall sampling (Windhorst et al., 2013) or shallow groundwater springs (Maldonado et al., 1995) or by using International Atomic Energy Agency (IAEA) weather stations (Rozanski and Araguas-Araguas, 1995; Garcia et al., 1998). Here, we use a flow accumulation model in ArcGIS (see above). $\delta^{18} \mathrm{O}$ values of samples collected along the Puerto Inca transect and plotted against mean catchment elevation yield a slope of $-0.15 \% / 100 \mathrm{~m}$ (Figure $3 \mathrm{~A} ; \mathrm{R}^{2}=0.88, n=19$ ). The $\delta \mathrm{D}$ vs. elevation relationship displays a linear regression with a slope of $-1.4 \% / 100 \mathrm{~m}$ for $\delta \mathrm{D}$ (Figure $3 \mathrm{~B} ; \mathrm{R}^{2}=0.93, n=19$ ). This result is also supported by the linear regression calculated from the Pasaje transect that gives a slope of $-0.15 \% / 100 \mathrm{~m}\left(\mathrm{R}^{2}=0.65\right.$, $n=30)$ for $\delta^{18} \mathrm{O}$ and $-1.4 \% \mathrm{o} / 100 \mathrm{~m}$ for $\delta \mathrm{D}\left(\mathrm{R}^{2}=0.78, n=30\right)$ (Figures 3A,B).

In the Inter-Andean valley, the correlation between $\delta^{18} \mathrm{O}$ values and elevation is absent, especially along the Yanuncay River and Nabón area (Figure 1A). An isotope-elevation relationship of $-0.28 \%$ o $/ 100 \mathrm{~m}$ for $\delta^{18} \mathrm{O}\left(\mathrm{R}^{2}=0.52\right.$, Figure $\left.3 \mathrm{~A}\right)$ and $-1.1 \% / 100 \mathrm{~m}$ for $\delta \mathrm{D}\left(\mathrm{R}^{2}=0.33\right.$, Figure $\left.3 \mathrm{~B}\right)$ can be defined from samples collected to the north of Cuenca (Burgay River) but display low correlation coefficients.

When plotting $\delta^{18} \mathrm{O}$ values from all samples against mean catchment elevation, a linear regression vs. elevation can be defined and provides a slope of $-0.18 \% / 100 \mathrm{~m}$ (Figure 3A; $\left.\mathrm{R}^{2}=0.73, n=83\right)$. Similarly, all $\delta \mathrm{D}$ values vs. elevation yield a slope of $-1.47 \%$ o $/ 100 \mathrm{~m}$ (Figure 3B; $\mathrm{R}^{2}=0.79, n=83$ ).

\section{DISCUSSION}

\section{Impact of Pacific Air Masses on Stable Isotopes in Precipitation}

The spatial patterns of $\delta \mathrm{D}$ and $\delta^{18} \mathrm{O}$ values of stream waters collected in southern Ecuador across the Western Cordillera and the Inter-Andean depression reflect the topography of this region. First, samples collected from the windward flanks of the Western Cordillera between Puerto Inca and El Cajas National Park (Figure 1A) show a net decrease in both $\delta \mathrm{D}$ and $\delta^{18} \mathrm{O}$ values (50\% in $\delta \mathrm{D}$ and $6 \%$ in $\delta^{18} \mathrm{O}$ from near sea level to $\sim 4,000 \mathrm{~m}$ ) across the mountain range (Figure 1C). This decrease in both $\delta^{18} \mathrm{O}$ and $\delta \mathrm{D}$ values allows to define an isotopic lapse rate of $-0.15 \%$ o $/ 100 \mathrm{~m}$ for $\delta^{18} \mathrm{O}\left(\mathrm{R}^{2}=0.88\right.$; Figure $\left.3 \mathrm{~A}\right)$ and $-1.4 \% \mathrm{o} / 100 \mathrm{~m}$ for $\delta D\left(R^{2}=0.93\right.$; Figure $\left.3 B\right)$. We interpret this lapse rate to reflect the altitude effect for $\delta \mathrm{D}$ and $\delta^{18} \mathrm{O}$ originating from Pacific air masses and orographic rainout on the western facing slopes of the Ecuadorian Andes.

Although calculated from samples sourced at lower elevation, the lapse rate from the Pasaje transect provides a $\delta^{18} \mathrm{O}$ and $\delta \mathrm{D}$ vs. altitude relationship of $-0.15 \% / 100 \mathrm{~m} \quad\left(\delta^{18} \mathrm{O} ; \mathrm{R}^{2}=0.65\right.$; Figure 3A) and $-1.4 \% / 100 \mathrm{~m}\left(\delta \mathrm{D} ; \mathrm{R}^{2}=0.78\right.$; Figure 3B $)$ and confirms the altitude effect on the isotope composition of tropical rains observed at higher elevation. These lapse rates are lower than those compiled or modeled for mid-latitude settings $(-0.28$ $\% / 100 \mathrm{~m}$ in $\delta^{18} \mathrm{O}$ or $-2.0 \% / 100 \mathrm{~m}$ in $\delta \mathrm{D}$ ) (e.g., Poage and Chamberlain, 2001; Quade et al., 2011). However, they are in good agreement with isotope-elevation relationships defined from the isotopic composition of tropical rains in Cameroon $\left(-0.156 \% / 100 \mathrm{~m}\right.$ in $\delta^{18} \mathrm{O}$; Gonfiantini et al., 2001), in the Colombian Eastern Cordillera $\left(-0.18 \% / 100 \mathrm{~m}\right.$ in $\delta^{18} \mathrm{O}$ and $-1.46 \% / 100 \mathrm{~m}$ in $\delta \mathrm{D}$; Saylor et al., 2009) and in Ecuador $\left(-0.17 \%\right.$ o $/ 100 \mathrm{~m}$ in $\delta^{18} \mathrm{O}$; Garcia et al., 1998) using water samples from springs and IAEA weather stations along two transects across the Western and Eastern Cordillera near 1 and $3^{\circ} \mathrm{S}$ latitude (Supplementary Table S1 and Supplementary Figure $2 S$ ). In the latter study, $\delta^{18} \mathrm{O}_{\text {water }}$ and $\delta \mathrm{D}_{\text {water }}$ values are influenced by the amount of precipitation which varies over the year and causes $\mathrm{D}$ and ${ }^{18} \mathrm{O}$-depleted precipitation during the wet season. In addition to this amount effect, Garcia and coauthors highlight a latitudinal effect in their dataset which is also well illustrated in our data, as $\delta^{18} \mathrm{O}_{\text {water }}$ values are $\sim-3 \%$ more negative to the north along the Puerto Inca transect (Figures 1C,2). The latitudinal difference for our low elevation sites that share the same Pacific moisture source can be explained by a lower precipitation amounts in the south (from Pasaje to La Tarabita) when compared to the north (Puerto Inca).

\section{Comparison Between Results Obtained Along the Puerto Inca and Pasaje Transects} Samples collected along the Puerto Inca and Pasaje transects define a similar elevation lapse rate of $-0.15 \% / 100 \mathrm{~m}$ for $\delta^{18} \mathrm{O}$. However, we note a better correlation for Puerto Inca than for Pasaje that can be explained by two main factors shared by Puerto Inca samples: 1) the location on the windward side of the Western Cordillera and, 2) an unique moisture source (the Pacific Ocean). Although the main moisture source for samples collected along the Pasaje transect is provided by the Pacific trade winds, we cannot preclude the possibility of mixing with Atlantic air masses that experienced evapo-transpiration over the Amazon (Salati et al., 1979). This is consistent with the observation of moist air masses along the Pasaje transect through side valleys (e.g., to the south-east of La Tarabita, black arrow on Figure 1A). In addition, evaporation associated with the dry climate that characterizes part of this transect could explain some of the variability in the results with enrichment of ${ }^{18} \mathrm{O}$ and D (e.g., Schemmel et al., 2013) observable in some samples (e.g., WS13 and WS24, Supplementary Table S1).

\section{The Inter-Andean Valley}

In contrast to samples from the windward side of the Western Cordillera, $\delta^{18} \mathrm{O}$ and $\delta \mathrm{D}$ values from the Cuenca region, in the Inter-Andean valley and further south in the Nabón Basin, do not show a clear correlation with elevation.

Data acquired along the Puerto Inca transect on the leeward side of the Western Cordillera display relatively low $\delta^{18} \mathrm{O}$ and $\delta \mathrm{D}$ values that can be explained by Rayleigh distillation of the heavy isotopes on the windward side (Figure 1C). However, together with data acquired from tributaries along the Yanuncay River (from sample 51 to 60 on Figure 1C and Supplementary Table S1), the $\delta^{18} \mathrm{O}$ and $\delta \mathrm{D}$ values on the leeward side cannot be correlated with elevation and show increased variability. However, leeward $\delta^{18} \mathrm{O}$ and $\delta \mathrm{D}$ vs. elevation gradients are 
inherently more complex once an orographic rain shadow develops (e.g., Quade et al., 2011). In addition to local evaporation that may shift near surface ground water $\delta^{18} \mathrm{O}$ and $\delta \mathrm{D}$ values to higher values (consistent with $\mathrm{d}=14.0 \pm$ $3.7),{ }^{18} \mathrm{O}$ or $\mathrm{D}$-depleted precipitation from the windward side, moisture mixing, and continental water vapor recycling represent multiple and confounding factors that render the interpretation of leeward rainfall $\delta^{18} \mathrm{O}$ and $\delta \mathrm{D}$ signals difficult (e.g., Blisniuk and Stern, 2005; Schemmel et al., 2013). Also, stable isotopic variability in our dataset could reflect the passage of the ITCZ, which significantly affects this area as highlighted by the BMR (Celleri et al., 2007). However, the ENSO system seems to have a negligible effect on the basin's seasonal distribution of rainfall due to the high elevation of the Cuenca area (1840-4680 m; Celleri et al., 2007).

Second, the $\delta^{18} \mathrm{O}$ and $\delta \mathrm{D}$ values acquired north of Cuenca, between Azogues and La Escalera (Figure 1A) show a weak correlation with altitude that allows to define a $\delta^{18} \mathrm{O}$ vs. elevation relationship of $-0.28 \%$ o $/ 100 \mathrm{~m}$ with $\mathrm{R}^{2}=0.52(-1.1 \% \mathrm{o} / 100 \mathrm{~m}$ with $\mathrm{R}^{2}=0.33$ for $\delta \mathrm{D}$ ) (see green line and samples on Figure 3). While the correlation coefficient is moderate, the isotopeelevation relationship is close to $-0.22 \%$ o/ $100 \mathrm{~m}$ for $\delta^{18} \mathrm{O}$ and $-1.12 \%$ o $/ 100 \mathrm{~m}$ for $\delta \mathrm{D}$ defined by Windhorst et al. (2013) who investigated the isotopic composition of precipitation in South Ecuadorian montane cloud forests from 1,800 to $2,800 \mathrm{~m}$ elevation using open rainfall sampling (on the east-facing slopes of the Andes in the San Francisco Valley). Windhorst et coauthors have highlighted an enrichment of heavy isotopes during southeasterly trade winds that carry re-evaporated and recycled precipitation from the Amazon Basin.

Results obtained from samples collected in the Nabón Basin display higher $\delta^{18} \mathrm{O}(>2 \%$ ), and $\delta \mathrm{D}(>13 \%)$ values than those measured from samples in the Cuenca Basin. No elevation lapse rate can be defined from these values that vary from -9.3 to $-7.5 \%$ for $\delta^{18} \mathrm{O}$, and -59 and $-44 \%$ for $\delta \mathrm{D}$. This lack of correlation with elevation could be partly explained by the small range of mean catchment elevations, which does not exceed $\sim 600 \mathrm{~m}$. In addition, and as highlighted in previous work conducted in South America (e.g., Nieto-Moreno et al., 2016), the variation of these tropical rainfall values could reflect a mixed signal resulting from different air mass trajectories.

\section{CONCLUSION}

We analysed the oxygen and hydrogen isotope ratios of surface waters from tributaries across the Ecuadorian Northern Andes to establish a $\delta^{18} \mathrm{O}$ and $\delta \mathrm{D}$ vs. elevation gradients near the Equator $\left(\sim 3^{\circ} \mathrm{S}\right)$; essential for stable isotope paleoaltimetry reconstructions.

The west facing slopes of the Western Cordillera are subject to moisture incoming from the Pacific which gets orographically lifted and produces a lapse rate of $-0.15 \% 0 / 100 \mathrm{~m}$ for $\delta^{18} \mathrm{O}\left(\mathrm{R}^{2}=\right.$ $0.88, n=19)$ and $-1.4 \%$ o $/ 100 \mathrm{~m}$ for $\delta \mathrm{D}\left(\mathrm{R}^{2}=0.93, n=19\right)$ that takes into account precipitation from near sea level up to $4,000 \mathrm{~m}$ elevation (Puerto Inca transect). This isotope-elevation relationship is supported by results acquired further south along the Pasaje transect that provides a similar result $\left[-0.15 \%\right.$ o $/ 100 \mathrm{~m}$ with $\mathrm{R}^{2}=0.65(n=30)$ for $\delta^{18} \mathrm{O}$ and $-1.4 \%$ / $100 \mathrm{~m}$ for $\delta \mathrm{D}$ with $\left.\mathrm{R}^{2}=0.78(n=30)\right]$, although covering a lower range of mean catchment elevation.

Evaluating the magnitude of $\delta^{18} \mathrm{O}$ and $\delta \mathrm{D}$ gradients across the Inter-Andean depression is more difficult as this domain receives air masses from the Pacific, Atlantic, and Amazon Basin. In addition, part of this region experiences the seasonal passage of the ITCZ that impacts the temperature and humidity of air masses. Therefore, the $\delta^{18} \mathrm{O}$ and $\delta \mathrm{D}$ values obtained from our water samples here reflect a mixed signal resulting from a combination of factors including air mass mixing, evaporation, humidity.

In agreement with previous studies conducted in Ecuador (e.g., Maldonado et al., 1995; Garcia et al., 1998; Jackson et al., 2019; Supplementary Table 1S and Supplementary Figure 2S) and other tropical regions (e.g., Gonfiantini et al., 2001; Saylor et al., 2009), our work demonstrates that an empirical relationship between elevation and the stable isotope composition of precipitation and surface waters can be established at (or near) the Equator. Therefore, the $\delta^{18} \mathrm{O}$ and $\delta \mathrm{D}$ elevation relationships of $-0.15 \% / 100 \mathrm{~m}$ for $\delta^{18} \mathrm{O}$ and $-1.4 \% / 100 \mathrm{~m}$ for $\delta \mathrm{D}$ may serve as a guide for stable isotope paleoaltimetry reconstructions at tropical latitudes.

\section{DATA AVAILABILITY STATEMENT}

The original contributions presented in the study are included in the article/Supplementary Material, further inquiries can be directed to the corresponding author.

\section{AUTHOR CONTRIBUTIONS}

AG wrote the manuscript, made the figures, and conducted the study (collection of water samples in the field, results analysis and interpretation). CW participated in writing the manuscript, made some figures and collected samples in the field. MR collected samples in the field, participated in the results analysis and interpretation. AM participated in writing and interpreting the data.

\section{ACKNOWLEDGMENTS}

We thank Ulrich Treffert (Senckenberg BiK-F) for continuous laboratory support. Comments and suggestions by L. J. Jackson, two anonymous reviewers and the editor, A. Licht, are gratefully acknowledged.

\section{SUPPLEMENTARY MATERIAL}

The Supplementary Material for this article can be found online at: https://www.frontiersin.org/articles/10.3389/feart.2021.664590/ full\#supplementary-material 


\section{REFERENCES}

Barnes, J. B., and Ehlers, T. A. (2009). End Member Models for Andean Plateau Uplift. Earth-Science Rev. 97, 105-132. doi:10.1016/j.earscirev.2009.08.003

Barnes, J. B., Ehlers, T. A., Insel, N., McQuarrie, N., and Poulsen, C. J. (2012). Linking Orography, Climate, and Exhumation across the central Andes. Geology 40 (12), 1135-1138. doi:10.1130/G33229

Blisniuk, P. M., and Stern, L. A. (2005). Stable Isotope Paleoaltimetry: a Critical Review. Am. J. Sci. 305 (10), 1033-1074. doi:10.2475/ajs.305.10.1033

Bookhagen, B., and Burbank, D. W. (2006). Topography, Relief, and TRMMDerived Rainfall Variations along the Himalaya. Geophys. Res. Lett. 33 (8), L08405. doi:10.1029/2006GL026037

Boos, W. R., and Kuang, Z. (2010). Dominant Control of the South Asian Monsoon by Orographic Insulation versus Plateau Heating. Nature 463, 218-222. doi:10. 1038/Nature08707

Campozano, L., Célleri, R., Trachte, K., Bendix, J., and Samaniego, E. (2016). Rainfall and Cloud Dynamics in the Andes: A Southern Ecuador Case Study. Adv. Meteorology 2016, 15. doi:10.1155/2016/3192765

Celleri, R., Willems, P., Buytaert, W., and Feyen, J. (2007). Space-time Rainfall Variability in the Paute basin, Ecuadorian Andes. Hydrol. Process. 21, 3316-3327. doi:10.1002/hyp.6575

Craig, H., and Gordon, L. I. (1965). "Deuterium and Oxygen-18 Variations in the Ocean and the marine Atmosphere," in Stable Isotopes in Oceanographic Studies and Paleotemperatures. Editor E. Tongiorgi Pisa: Consiglio Nazionale delle Riche, Laboratorio de Geologia Nucleare), 1-122.

Currie, B. S., Rowley, D. B., and Tabor, N. J. (2005). Middle Miocene Paleoaltimetry of Southern Tibet: Implications for the Role of Mantle Thickening and Delamination in the Himalayan Orogen. Geol. 33 (3), 181-184. doi:10.1130/ G21170.1

Ehlers, T. A., and Poulsen, C. J. (2009). Influence of Andean Uplift on Climate and Paleoaltimetry Estimates. Earth Planet. Sci. Lett. 281 (3-4), 238-248. doi:10. 1016/j.epsl.2009.02.026

Emck, P. (2007). "A Climatology of South Ecuador - with Special Focus on the Major Andean ridge as Atlantic-Pacific Climate divide,", 1-159. FriedrichAlexander-University of Erlangen-Nurnberg. PhD.

Garcia, M., Villalba, F., Araguas-Araguas, L., and Rozanski, K. (1998). “The Role of Atmospheric Circulation Patterns in Controlling the Regional Distribution of Stable Isotope Contents in Precipitation: Preliminary Results from Two Transects in the Ecuadorian Andes," in Isotope Techniques in the Study of Environmental Change (Vienna: International Atomic Energy Agency), $127-140$.

Garreaud, R. D., Vuille, M., Compagnucci, R., and Marengo, J. (2009). Present-day South American Climate. Palaeogeogr. Palaeoclimatol. Palaeoecol. 281, 180-195. doi:10.1016/j.palaeo.2007.10.032

Garzione, C. N., Hoke, G. D., Libarkin, J. C., Withers, S., MacFadden, B., Eiler, J., et al. (2008). Rise of the Andes. Science 320, 1304-1307. doi:10.1126/science. 1148615

Garzione, C. N., McQuarrie, N., Perez, N. D., Ehlers, T. A., Beck, S. L., Kar, N., et al. (2017). Tectonic Evolution of the Central Andean Plateau and Implications for the Growth of Plateaus. Annu. Rev. Earth Planet. Sci. 45, 529-559. doi:10.1146/ annurev-earth-063016-020612

Garzione, C. N., Molnar, P., Libarkin, J. C., and MacFadden, B. J. (2006). Rapid Late Miocene Rise of the Bolivian Altiplano: Evidence for Removal of Mantle Lithosphere. Earth Planet. Sci. Lett. 241 (3-4), 543-556. doi:10.1016/j.epsl. 2005.11.026

Garzione, C. N., Quade, J., DeCelles, P. G., and English, N. B. (2000). Predicting Paleoelevation of Tibet and the Himalaya from $\delta 18 \mathrm{O}$ vs. Altitude Gradients in Meteoric Water across the Nepal Himalaya. Earth Planet. Sci. Lett. 183, 215-229. doi:10.1016/S0012-821X(00)00252-1

Gébelin, A., Mulch, A., Teyssier, C., Jessup, M. J., Law, R. D., and Brunel, M. (2013). The Miocene Elevation of Mount Everest. Geology 41, 799-802. doi:10.1130/ G34331.1

Gébelin, A., Mulch, A., Teyssier, C., Page Chamberlain, C., and Heizler, M. (2012). Coupled basin-detachment Systems as Paleoaltimetry Archives of the Western North American Cordillera. Earth Planet. Sci. Lett. 335-336, 36-47. doi:10. 1016/j.epsl.2012.04.029
Gonfiantini, R., Roche, M.-A., Olivry, J.-C., Fontes, J.-C., and Zuppi, G. M. (2001). The Altitude Effect on the Isotopic Composition of Tropical rains. Chem. Geology. 181, 147-167. doi:10.1016/s0009-2541(01)00279-0

Gregory-Wodzicki, K. M. (2000). Uplift History of the Central and Northern Andes: A Review. Geol. Soc. America Bull. 112 (7), 1091-1105. doi:10.1130/ 0016-7606(2000)112<1091:UHOTCA >2.0.CO;2

Hungerbühler, D., Steinmann, M., Winkler, W., Seward, D., Egüez, A., Peterson, D. E., et al. (2002). Neogene Stratigraphy and Andean Geodynamics of Southern Ecuador. Earth-Science Rev. 57, 75-124. doi:10.1016/S0012-8252(01)00071-X

Jackson, L. J., Horton, B. K., Beate, B. O., Bright, J., and Breecker, D. O. (2019). Testing Stable Isotope Paleoaltimetry with Quaternary Volcanic Glasses from the Ecuadorian Andes. Geology 47, 411-414. doi:10.1130/G45861.1

Maldonado, A. S., Cepeda, T. H., and Araguás Araguás, L. (1995). "Hydrogeological and Isotopic Study of Groundwater in the ChacrasHuaquillas Area (Ecuador)," International Atomic Energy Agency Technical Document IAEA-TECDOC-835, 195-209.

Molnar, P., and England, P. (1990). Late Cenozoic Uplift of Mountain Ranges and Global Climate Change: Chicken or Egg? Nature 346 (6279), 29-34. doi:10. 1038/346029a0

Mora, D. E., Campozano, L., Cisneros, F., Wyseure, G., and Willems, P. (2014). Climate Changes of Hydrometeorological and Hydrological Extremes in the Paute basin, Ecuadorean Andes. Hydrol. Earth Syst. Sci. 18 (2), 631-648. doi:10. 5194/hess-18-631-2014

Mulch, A., Graham, S. A., and Chamberlain, C. P. (2006). Hydrogen Isotopes in Eocene River Gravels and Paleoelevation of the Sierra Nevada. Science 313, 87-89. doi:10.1126/science. 1125986

Mulch, A. (2016). Stable Isotope Paleoaltimetry and the Evolution of Landscapes and Life. Earth Planet. Sci. Lett. 433, 180-191. doi:10.1016/j.epsl.2015.10.034

Mulch, A., Teyssier, C., Cosca, M. A., Vanderhaeghe, O., and Vennemann, T. W. (2004). Reconstructing Paleoelevation in Eroded Orogens. Geol. 32, 525-528. doi:10.1130/g20394.1

Nieto-Moreno, V., Rohrmann, A., van der Meer, M. T. J., Sinninghe Damsté, J. S., Sachse, D., Tofelde, S., et al. (2016). Elevation-dependent Changes in N -alkane $\delta \mathrm{D}$ and Soil GDGTs across the South Central Andes. Earth Planet. Sci. Lett. 453, 234-242. doi:10.1016/j.epsl.2016.07.049

Ochoa, A., Campozano, L., Sánchez, E., Gualán, R., and Samaniego, E. (2016). Evaluation of Downscaled Estimates of Monthly Temperature and Precipitation for a Southern Ecuador Case Study. Int. J. Climatol. 36 (3), 1244-1255. doi:10.1002/joc.4418

Philander, S. G. H. (1983). El Niño Southern Oscillation Phenomena. Nature 302, 295-301. doi:10.1038/302295a 0

Poage, M. A., and Chamberlain, C. P. (2001). Empirical Relationships between Elevation and the Stable Isotope Composition of Precipitation and Surface Waters: Considerations for Studies of Paleoelevation Change. Am. J. Sci. 301, 1-15. doi:10.2475/ajs.301.1.1

Quade, J., Breecker, D. O., Daeron, M., and Eiler, J. (2011). The Paleoaltimetry of Tibet: an Isotopic Perspective. Am. J. Sci. 311 (2), 77-115. doi:10.2475/02. 2011.01

Rech, J. A., Currie, B. S., Michalski, G., and Cowan, A. M. (2006). Neogene Climate Change and Uplift in the Atacama Desert, Chile. Geol. 34 (9), 761-764. doi:10. 1130/G22444.1

Rohrmann, A., Strecker, M. R., Bookhagen, B., Mulch, A., Sachse, D., Pingel, H., et al. (2014). Can Stable Isotopes Ride Out the Storm? the Role of Convection for Water Isotopes in Models, Records, and Paleoaltimetry Studies in the central Andes. Earth Planet. Sci. Lett. 407, 187-195. doi:10.1016/j.epsl.2014.09.021

Rollenbeck, R., and Bendix, J. (2011). Rainfall Distribution in the Andes of Southern Ecuador Derived from Blending Weather Radar Data and Meteorological Field Observations. Atmos. Res. 99 (2), 277-289. doi:10.1016/ j.atmosres.2010.10.018

Rossel, F., and Cadier, E. (2009). El Niño and Prediction of Anomalous Monthly Rainfalls in Ecuador. Hydrol. Process. 23, 3253-3260. doi:10.1002/hyp.7401

Rossel, F., Mejía, R., and Ontaneda, G. (1998). Régionalisation de l'influence du El Nino sur les précipitations de l'Equateur. Bull. Inst. Fr. Études Andines 27 (3), 643-654.

Rowley, D. B., and Garzione, C. N. (2007). Stable Isotope-Based Paleoaltimetry. Annu. Rev. Earth Planet. Sci. 35, 463-508. doi:10.1146/annurev.earth.35. 031306.140155 
Rozanski, K., and Araguas Araguas, L. (1995). Spatial and Temporal Variability of Stable Isotope Composition of Precipitation over the South American Continent. Bull. de l'Institut Francais d'études Andines 24 (3), 379-390.

Rozanski, K., Araguaś-Araguaś, L., and Gonfiantini, R. Isotopic Patterns in Modern Global Precipitation in Climate Change in Continental Isotopic Records: Geophysical Monograph Series. Editors P. K. Swart, K. C. Lohmann, J. McKenzie, and S. Savin 78, 1-36. doi:10.1029/GM078p0001

Salati, E., Dall'Olio, A., Matsui, E., and Gat, J. R. (1979). Recycling of Water in the Amazon Basin: An Isotopic Study. Water Resour. Res. 15 (5), 1250-1258. doi:10.1029/WR015i005p01250

Saylor, J. E., Mora, A., Horton, B. K., and Nie, J. (2009). Controls on the Isotopic Composition of Surface Water and Precipitation in the Northern Andes, Colombian Eastern Cordillera. Geochimica et Cosmochimica Acta 73, 6999-7018.doi:10.1016/j.gca.2009.08.030

Schemmel, F., Mikes, T., Rojay, B., and Mulch, A. (2013). The Impact of Topography on Isotopes in Precipitation across the Central Anatolian Plateau (Turkey). Am. J. Sci. 313 (2), 61-80. doi:10.2475/02.2013.01

Steinmann, M., Hungerbühler, D., Seward, D., and Winkler, W. (1999). Neogene Tectonic Evolution and Exhumation of the Southern Ecuadorian Andes: a Combined Stratigraphy and Fission-Track Approach. Tectonophysics 307, 255-276. doi:10.1016/s0040-1951(99)00100-6

Sundell, K. E., Saylor, J. E., Lapen, T. J., and Horton, B. K. (2019). Implications of Variable Late Cenozoic Surface Uplift across the Peruvian central Andes. Scientific Rep. 9, 4877. doi:10.1038/s41598-019-41257-3
Vuille, M., Bradley, R. S., and Keimig, F. (2000). Climate Variability in the Andes of Ecuador and its Relation to Tropical Pacific and Atlantic Sea Surface Temperature Anomalies. J. Clim. 13 (14), 2520-2535. doi:10.1175/15200442(2000)013<2520:CVITAO >2.0.CO;2

Windhorst, D., Waltz, T., Timbe, E., Frede, H.-G., and Breuer, L. (2013). Impact of Elevation and Weather Patterns on the Isotopic Composition of Precipitation in a Tropical Montane Rainforest. Hydrol. Earth Syst. Sci. 17 (1), 409-419. doi:10. 5194/hess-17-409-2013

Witt, C., Rivadeneira, M., Poujol, M., Barba, D., Beida, D., Beseme, G., et al. (2017). Tracking Ancient Magmatism and Cenozoic Topographic Growth within the Northern Andes Forearc: Constraints from Detrital U-Pb Zircon Ages. Geol. Soc. America Bull. 129 (3-4), 415-428. doi:10. 1130/B31530.1

Conflict of Interest: The authors declare that the research was conducted in the absence of any commercial or financial relationships that could be construed as a potential conflict of interest.

Copyright (C) 2021 Gébelin, Witt, Radkiewicz and Mulch. This is an open-access article distributed under the terms of the Creative Commons Attribution License (CC BY). The use, distribution or reproduction in other forums is permitted, provided the original author(s) and the copyright owner(s) are credited and that the original publication in this journal is cited, in accordance with accepted academic practice. No use, distribution or reproduction is permitted which does not comply with these terms. 